\title{
An Examination on D. Shostakovich's Viola Sonata Op.147 from a Technical Perspective
}

\section{Shostakovich Viyola Sonati Op.147 Üzerine Teknik Açidan Bir İnceleme}

\author{
Füsun Naz ALTINEL ${ }^{1}$ (D)
}

'Dr., Karşıyaka Belediyesi Oda OrkestrasıViyola Sanatçısı, İzmir, Türkiye

ORCID: F.N.A. 0000-0002-1506-8994

Corresponding author/Sorumlu yazar: Füsun Naz Altınel,

Karşıyaka Belediyesi Oda Orkestrası-Viyola Sanatçısı, İzmir, Türkiye

E-mail/E-posta: nazaltinel@gmail.com

Submitted/Başvuru: 02.09 .2020

Revision Requested/ilk Revizyon: 05.11.2020 Last Revision Requested/Son Revizyon: 22.11.2020

Accepted/Kabul: 23.11.2020

Citation/Atıf: Altinel, F.N. (2020). An Examination on D. Shostakovich's Viola Sonata Op.147 "Personal Freedom in the Light of Death. Konservatoryum - Conservatorium, 7(2), 89-104.

https://doi.org/10.26650/CONS2020-0011

\begin{abstract}
The purpose of this article is to provide a resource to those who wish to gain a deeper understanding on the technical aspects of Shostakovich's Viola Sonata Op. 147 based on F. Druzhinin's edited viola part. This study consists of two methods; books are used as research material to provide an overview on composers life and music, extracts from F. Druzhinin's viola part and recordings are examined to provide technical suggestions to performers. Preparing this article, books and $\mathrm{F}$. Druzhinin's viola part are obtained from the library of Royal Northern College of Music. For the recording of Fyodor Druzhinin, youtube is used as online resource. The headlines inside the study are as follows; an overview of Shostakovich's life and viola sonata, other composers and artists that have influenced Shostakovich's music (Ludwig Van Beethoven and Nicolai Gogol) and performance suggestions given based on F. Druzhinin's viola part and recording. For the music examples in this article Moscow: Publishers Musika, 1984, Collected Works in forty-two volumes: (Vol.38, viola part edited by F. Druzhinin) is used.
\end{abstract}

Keywords: Shostakovich, Viola, Sonata

öz

Bu makalenin amacı Shostakovich'in Op. 147 viyola Sonatını çalışmak isteyen yorumculara F.Druzhinin'in düzeltmelerini içeren viyola partisi üzerinde yapılan teknik çalışmalar ile yararlı bir kaynak oluşturmaktır. Bu çalışma iki method kullanmaktadır; bestecinin hayatı ve müziği üzerine genel bir bakış oluşturmak üzere kitaplar incelenerek literatür taraması yapılmış, F.Druzhinin'in düzeltmelerini içeren viyola partisi ve eserin kaydı incelenerek yorumculara teknik öneriler sunulmuştur. Çalışmanın yazım sürecinde kullanılmış olan kitaplar ve F.Druzhinin'in düzeltmelerini içeren viyola partisi Royal Northern College of Music kütüphanesinden alınmıştır. Fyodor Druzhinin'e ait olan kayıt için ise çevrimiçi kaynaklardan youtube'dan faydalanılmıstır. Çalışmanın ara başlıkları şu şekildedir; Shostakovich'in hayatı ve viyola sonatı üzerine genel bir bakış, bestecinin müzikal dilini etkilemiş olan diğer besteci ve sanatçılar (Ludwig Van Beethoven ve Nicolai Gogol) ve F. Druzhinin'in düzeltmelerini içeren viyola partisi üzerinde performansa yönelik öneriler. Bu makaledeki müzik örnekleri Moscow: Publishers Musika, 1984, Collected Works in forty-two volumes: (Vol.38, viola part edited by F. Druzhinin) esas alınarak oluşturulmuştur.

Anahtar Kelimeler: Shostakovich, Viyola, Sonat 


\section{Introduction}

\section{Methodology}

In this article two types of methods are used. First books about composers' life and articles about the viola sonata are used to provide background information then, analysis of the extracts from the viola part edited by F. Druzhinin is used as the main material to provide performance suggestions. Other musical examples such as extracts taken from D. Shostakovich's opera The Gamblers Op. 63 where the woodwind and brass solos are used in the second movement of the viola sonata, L.V. Beethoven's Moonlight Sonata Op.27 and clarinet solo from Strauss' Quixote Op.35, which are used in the third movement of the viola sonata, are given to show the performer where the quotations originally come from as extra information. Knowing the background information of the composers' life and the sonata performer can develop a deeper understanding of how to interpret the music. On the other hand, observing bowings and fingerings on F. Druzhinin's edited viola part gives performers a clearer idea on how to interpret the sonata and which string techniques can be used.

\section{An Overview of Shostakovich's Life and Viola Sonata}

Shostakovich spent all his life under the regime of the Soviet Union, which dissolved in 1991, sixteen years after his death. But while his final piece may have allowed him some form of personal freedom, his memory was still manipulated by the regime so that he could appear as the poster child for Soviet music. The official obituary, provided in Pravda, said that as; "A faithful son of the Communist Party, an eminent social and government figure, citizen-artist D.D.S. devoted his entire life to the development of Soviet music, reaffirming the ideals of socialist humanism and internationalism [...] " (Roseberry, 1982, p.175).

This shows the strict control of the media within the state, which were always presented the government's view and ideals, effectively censoring the information available to the public. Openly expressing feelings or attitudes against the Soviet Union, however, inevitably led to strong repercussions, forcing citizens to comply with the regulations in order to stay alive within the system. Hence the music was controlled by the ideals of the regime rather than by the musical value of pieces, and criticism by renown artists such as Mstislav Rostropovich remained unheard due to the censorship of the media (Roseberry, 1982, p.167). 
Particularly due to his official position and dependency on the state, Shostakovich was therefore forced to work in a detached professional persona rather than being able to express his actual feelings. This left him in a struggle between composing for the regime and criticising the actual conditions in his society. This dilemma can best be observed in the difference between his pieces composed in celebration of anniversaries related to Soviet Union such as October Op.131, Loyalty Op. 136 and March of the Soviet Militia Op. 139 and the pieces showing his attitude towards the system such as his Eighth Quartet dedicated 'to the victims of fascism and war' and his Fifth Symphony subtitled 'Creative reply of a Soviet Artist to Just Criticism' (Maurice, 2000, p.13).

When looking at Shostakovich's works, one can be surprised by the number of dedications he has made to individuals. This emphasis on valuing the individual could also be seen as an attitude against the Soviet Union's ideal of promoting collective memory. It is also a self-evident fact that Shostakovich was likewise concerned about being remembered as an individual himself. Therefore he chose to write his own requiem in the form of an intimate, purely instrumental chamber work (Wilson, E., 2012, p.80).

The viola sonata was Shostakovich's final work and was completed in his last days when he was suffering from poor health in hospital. Despite this reality, his creative energy stayed undiminished and his attitude towards death shifted away from the pessimism and focussed on his remaining music being optimistic (Roseberry, 1982, p.174). It can be seen in his letter to Fyodor Druzhinin to whom the viola sonata is dedicated; "[...] The last movement is in memory of Beethoven [...]. But don't let that inhibit you. The music is bright, bright and clear" (Fay, 2000, p.286).

The viola sonata was originally intended for cello and to be dedicated to the internationally acclaimed Soviet cellist Rostropovich. But due to the political circumstances that hindered open communication between the composer and the cellist, the piece was changed to fit the viola instead. The choice of the instrument is rather a typical one, though, as it mirrors the choices of other composers such as Mozart, Bartók and Bruch (Maurice, 2000, p.13). Additionally as an instrument the viola has the tendency to represent the melancholic character and is frequently used to bring out a dark and hopeless sound. These characteristics of the instrument explain the choice of the viola for this piece that includes all these elements of satire, melancholy and deep darkness. 
Moreover, in the viola sonata the composer reflects upon his life, looking back from a distance by using self-quotations and also a quotation taken from Richard Strauss' Don Quixote, which represents the moment of the soul leaving the hero's body and was originally written for clarinet, is particularly interesting (Sokolov, I., 2012, p. 83-94).

There have been many interpretations, since the sonata was written, by internationally acclaimed soloists such as Kim Kashkashian, Nobuko Imai, Thomas Riebl and Lawrence Power. However as the piece was dedicated to Fyodor Druzhinin, I chose to focus on his edited version of the score, especially when taking into account the great soloists of the Soviet Union and their authority in string playing.

\section{The Composers and Artists That Have Influenced Shostakovich's Music}

\section{Ludwig Van Beethoven}

According to Schwarz, Beethoven was a favourite in the Soviet regime, as he was in tune with the social aspirations of his age, which was expected from Shostakovich too, with him being seen as the Soviet version of Beethoven (Roseberry, 1982, p. 62-63). Therefore this similarity shows itself in Shostakovich's middle period symphonies which can be compared with "Beethoven's ideals of revolutionary humanism and broad humanity” (Roseberry, 1982, p.15).

Even in his final viola sonata in third movement, Shostakovich pays tribute to Beethoven as a person, quoting his one of the most popular pieces, the "Quasi una fantasia" subtitled Moonlight Sonata Op.27. This shows a similarity between the two composers, who both had two distinctive inspirations: the heroic revolutionary idea and more personal emotional idea.

\section{Nicolai Gogol}

Another influence that had a special impact on the viola sonata was the Russian writer Gogol, who like Dostoyevski was a representative of the existentialist literature. Gogol made a fascinating observation in foreseeing the issues of the Soviet Union in a satirical and grotesque style in his short story The Nose (Roseberry, 1982, p.174).

Shostakovich had started to compose an opera based on Gogol's play The Gamblers, in which he based the libretto on the writer's own words in unchanged form. The composer never finished the opera, though, as its content was neither patriotic nor heroic, but rath- 
er an unrealistic satirical comparison of the political situation to a card game and he expected it to not be performed (Volkov, 1979, p. 172). More than thirty years after this attempt, Shostakovich finally had the opportunity to use part of this opera score for the second movement of the viola sonata, now finally free of the expectations and limitations of his earlier career.

\section{Performance Suggestions Given Based On F. Druzhinin's Viola Part And Recording}

\section{First Movement - Moderato}

Each movement of the viola sonata reflects different ideas: the first movement relates back to the baroque compositional techniques, which the composer combines with the musical language of the $20^{\text {th }}$ century (MacDonald, 2008, p. 142-143). Another striking feature is that the movement is mainly based on two opposite ideas: the chord-based, broken melody first presented by the viola, and the lyrical and linear twelve tone material first presented in the piano part $\mathrm{RH}$.

The piece starts with a pizzicato in the solo viola, which shows a rising and falling pattern in phrases of two bars. This allows for an untypical melodic interpretation of the pizzicato passage, due to the chord-based broken melody.

When listening to the recording of F. Druzhinin it can be seen that he has chosen to be loyal to the tempo directive given by the composer which equals to crochet 104 (Druzhinin, 1975, s.0.00-0.09). In the opening section it can be seen that he has chosen to play the whole passage with vibrato (Figure 1, Druzhinin, 1975, s.0.21-0.28).

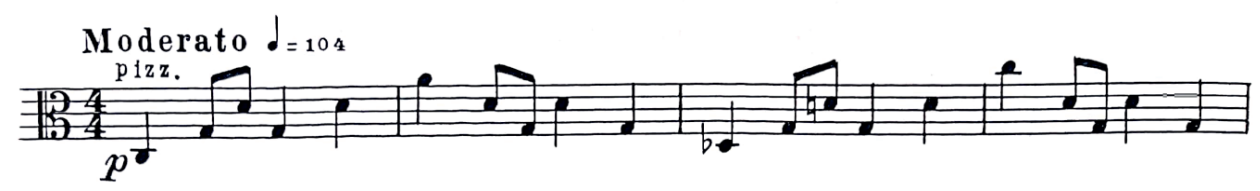

Figure 1. Shostakovich, Sonata for Viola and Piano Op. 147, 1st movement bars 1-4 (Shostakovich, 1975, p.2)

The composer's experience with vocal melodies and his interest in classical works for the voice have influenced his instrumental pieces, giving them fluency through the voice-like linear lines in the instruments, as here in the viola. This passage has two op- 
tions for interpretation, the first, is as Druzhinin did, vibrato can start directly from the beginning of bar 10 and in the second, the passage can be interpreted with a pure sound using little vibrato combined with light and fluent bowing. Also, the two pizzicato notes ( $\mathrm{G}$ and $\mathrm{D}$ ) before bar number 10 could be interpreted with left hand pizzicato to prepare the right hand for arco (Figure 2).

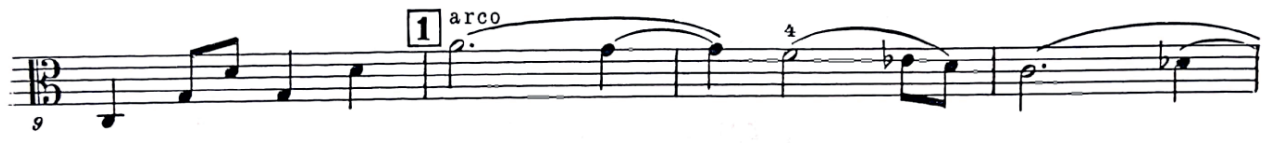

Figure 2. Shostakovich, Sonata for Viola and Piano Op. 147, 1st movement bars 9-12 (Shostakovich, 1975, p.2)

Broad progression of intervals towards the crescendo to forte could be achieved by using increased bow pressure with a simultaneous decrease in bow speed to enhance this tension as Druzhinin did. Then the final diminuendo allows for a release after the climax of the passage (Figure 3).

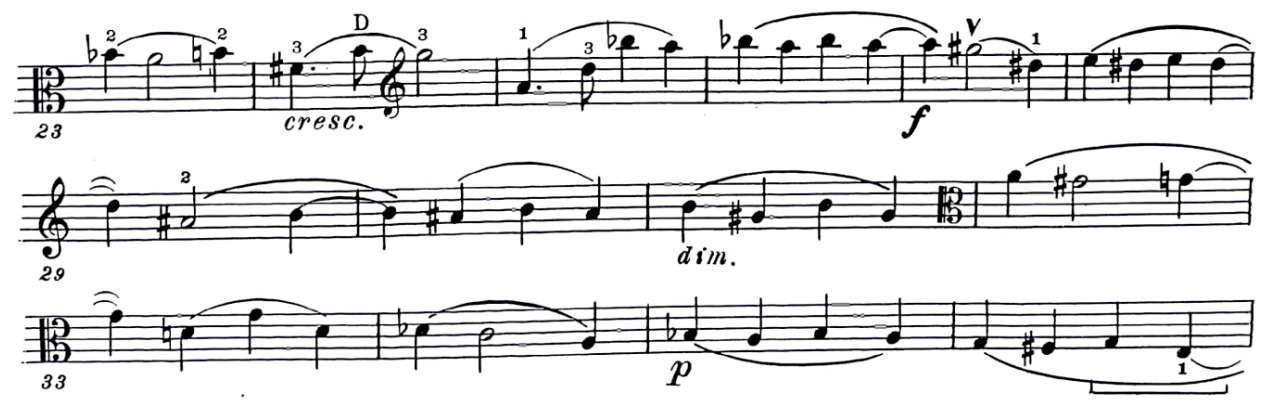

Figure 3. Shostakovich, Sonata for Viola and Piano Op. 147,

1st movement bars 23-4 (Shostakovich, 1975, p.2)

It is marked in F. Druzhinin's score, in bar 38 that the two notes G and C can be play with left hand pizzicato to make the arco to pizzicato change smoothly (Figure 4). 


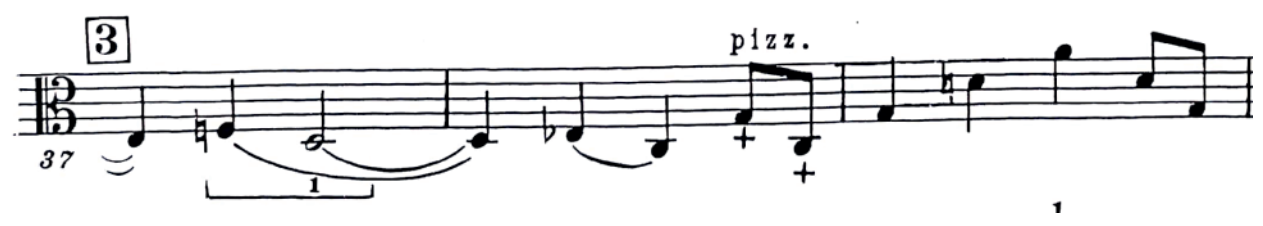

Figure 4. Shostakovich, Sonata for Viola and Piano Op. 147, 1st movement bars 37-39 (Shostakovich, 1975, p.2)

The bowing suggestion given by Druzhinin above is an interpretive one to make the crescendo more effectively. It can be seen that he has chosen to use the support of the up bow (Figure 5).

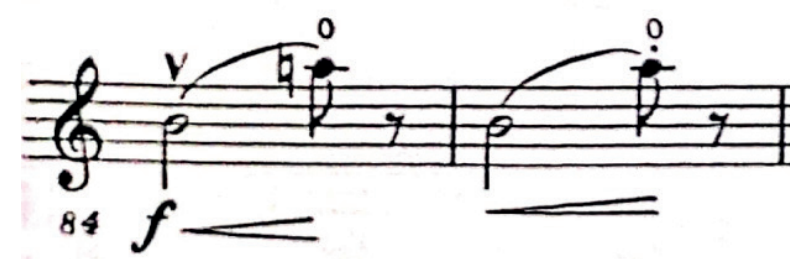

Figure 5. Shostakovich, Sonata for Viola and Piano Op. 147, 1st movement bars 84-85 (Shostakovich, 1975, p.3)

Another bowing suggestion is the consecutive use of the down bows which enhances the resonance of the chords (Figure 6).

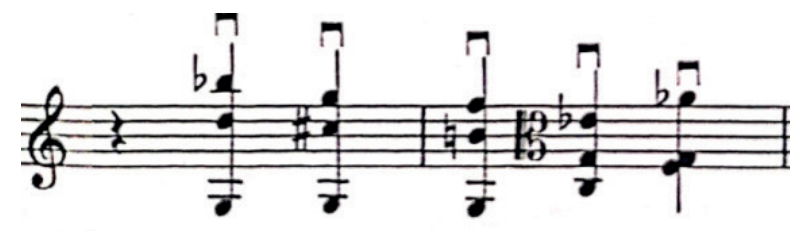

Figure 6. Shostakovich, Sonata for Viola and Piano Op. 147, 1st movement bars 86-87 (Shostakovich, 1975, p.3)

Shostakovich creates a spine-chilling effect using the orchestral technique of tremolo marked piano in the viola part in combination with the unusually high pitch and the instruction to play sul-ponticello (Figure 7). 


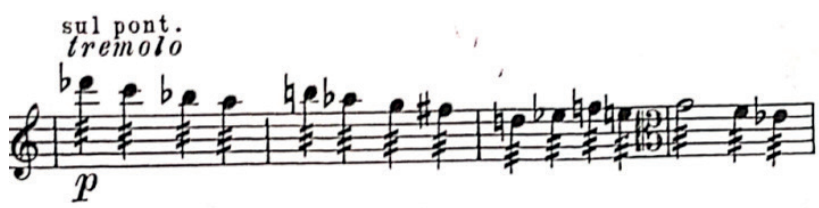

Figure 7. Shostakovich, Sonata for Viola and Piano Op. 147, 1st movement bars 161-164 (Shostakovich, 1975, p.5)

The tremolo passage which requires lower dynamics are generally advised to play at the tip of the bow. It can be seen in Druzhinin's part that he has chosen to start the next passage with an up bow which makes the change easier (Figure 8).

20

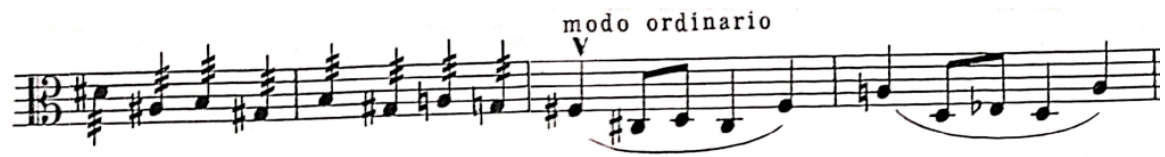

Figure 8. Shostakovich, Sonata for Viola and Piano Op. 147,

1st movement bars 169-172) (Shostakovich, 1975, p.5)

Fingering advice is given below by Druzhinin to play the passage below. In his viola part, it can be seen that he chose to stay in the same position rather than shifting up and down to avoid the possible intonation faults as well as to play the passage with less effort (Figure 9).

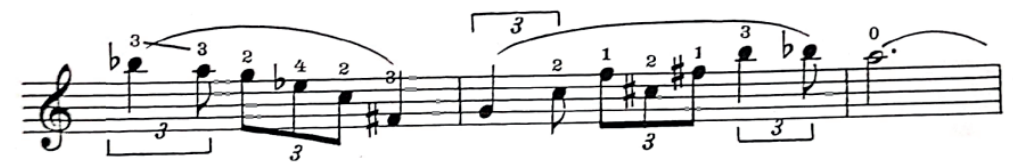

Figure 9. Shostakovich, Sonata for Viola and Piano Op. 147, 1st movement bars 182-184 (Shostakovich, 1975, p.5)

In the cadenza, two opposite ideas, which were taken from the opening section of the sonata, can be seen. The first one is triplets marked staccato then the linear line which is marked as piano dolce. This requires the performer to emphasise the contrast between 
these different ideas by interpreting the staccato parts as dryly as possible and off the string, while playing the dolce parts with a fluent bow in a resonating way. In Druzhinin's viola part it can be seen that he has chosen to play the staccato triplets starting with up bow and the dolce parts are played with down bow (Figure10).

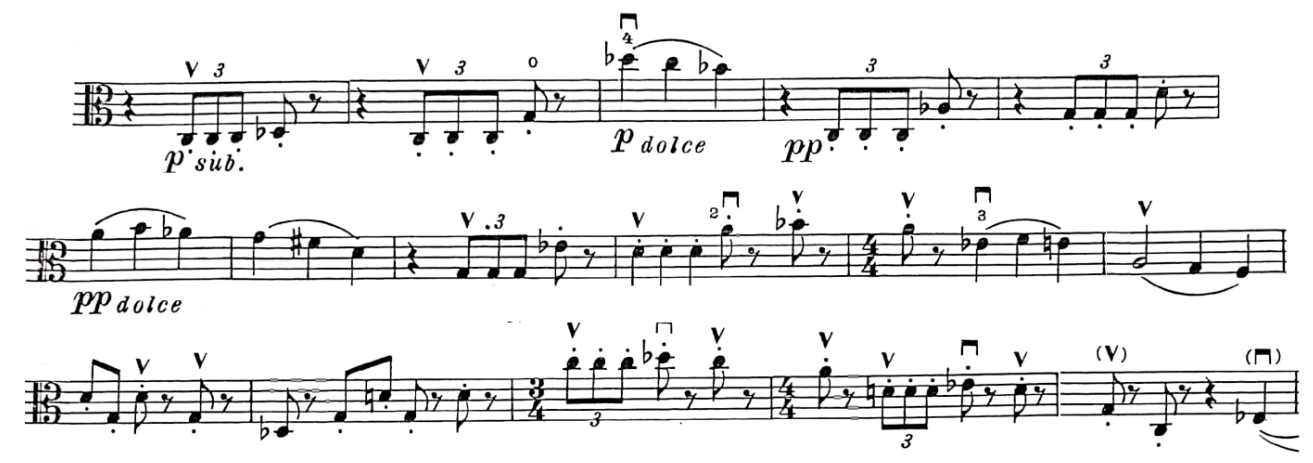

Figure 10. Shostakovich, Sonata for Viola and Piano Op. 147, 1st movement bars 222-237 (Shostakovich, 1975, p.6)

\section{Second Movement- Allegretto and Shostakovich's Opera The Gamb- lers Op.63}

The second movement, on the other hand, is based on Shostakovich's unfinished opera The Gamblers (Figure 11). This reduction of a full orchestration to two instruments brings about specific suggestions on the character of the passages: when faithful to the original orchestration Shostakovich, D. (1981) The Gamblers Op. 63 - Opera Scenes after N.V. Gogol [Score] Moscow: State Publishers, the viola is expected to imitate the sound of various wind instruments to achieve the specified intended timbre in each phrase. 


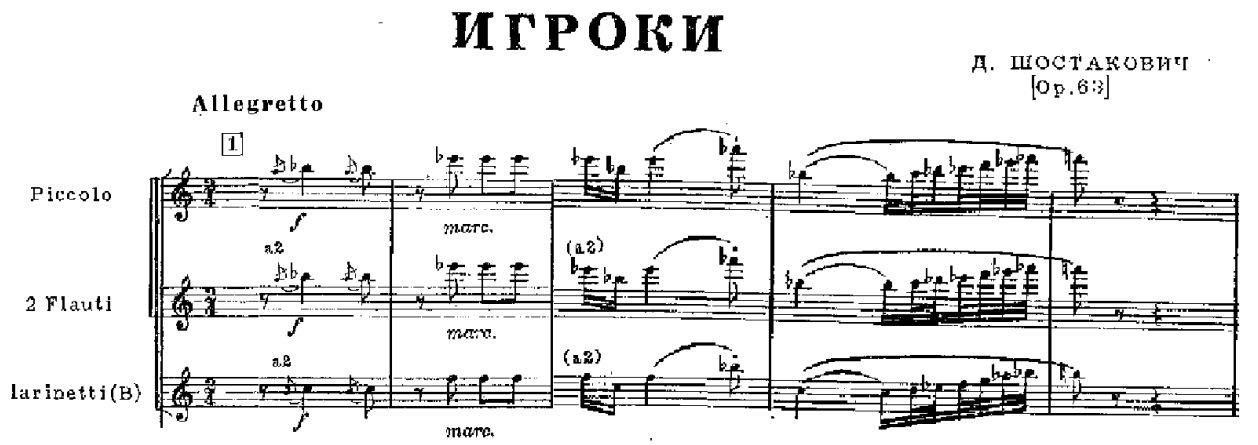

Figure 11. Shostakovich, The Gamblers Op. 63, Allegretto bars 5-7 (Shostakovich, 1981)

The examples below explain how to interpret the specified passages with the suggested bowings given by Fyodor Druzhinin, the dedicatee of the work. To imitate the sharp articulation of upper wind instruments, the violist can use light and extra short repeated up bows when playing the staccato notes. In addition, to achieve the screaming effect of the quick crescendo at bar 6 , the player should start the passage on an up bow with a very soft dynamic and increase the pressure gradually whilst increasing the pace of the bow till achieving forte (Figure 12).

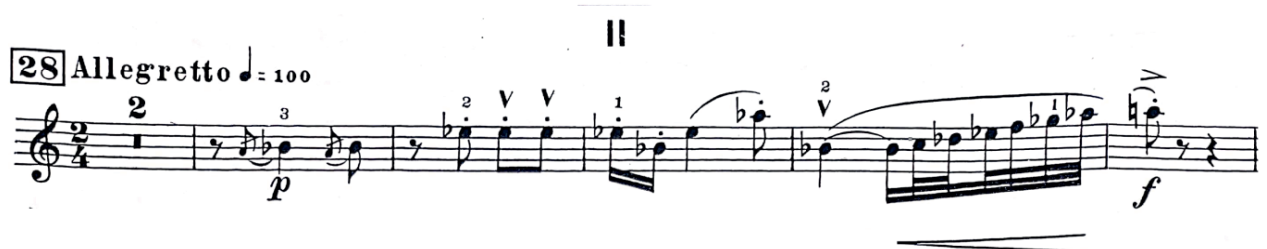

Figure 12. Shostakovich, Sonata for Viola and Piano Op. 147, 2nd movement bars 3-7 (Shostakovich, 1975, p.7)

When imitating the bright and bold sound of trumpets in the following passage (Figure 13), the violist can use the string technique marcato to achieve heavy and sustained bow strokes on the string when playing the accents (Figure 14). 


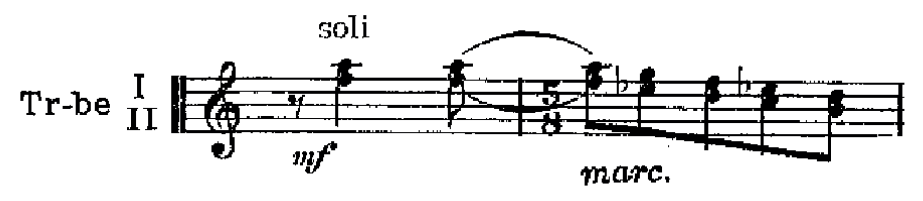

Figure 13. Shostakovich, The Gamblers Op. 63, Allegretto bars 32-33 (Shostakovich, 1981)

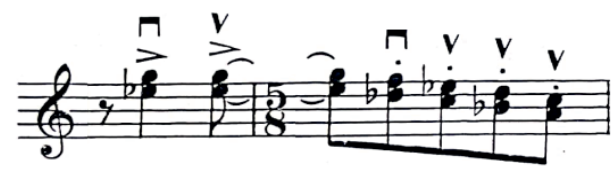

Figure 14. Shostakovich, Sonata for Viola and Piano Op. 147,

2nd movement bars 30-31 (Shostakovich, 1975, p.7)

In the next passage the composer combines the bright sound of the oboe with the lyrical sound of the clarinets (Figure 15).

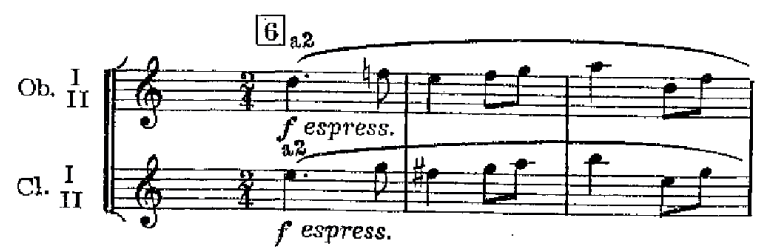

Figure 15. Shostakovich, The Gamblers Op. 63, Allegretto bars 51-53 (Shostakovich, 1981)

In Druzhinin's viola part it can be seen that, to play this linear melody he chose to stay in the same position to avoid up and down shifts which would interrupt the melody line (Figure 16).

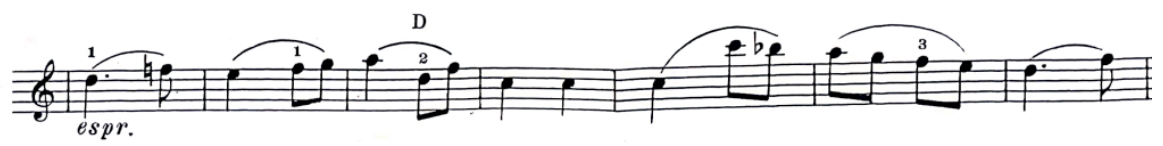

Figure 16. Shostakovich, Sonata for Viola and Piano Op. 147, 2nd movement bars 49-55 (Shostakovich, 1975, p.7) 
Another interpretive suggestion is to play the passage below the $\mathrm{C}$ string to achieve a more characteristic and powerful sound (Figure 17, Druzhinin, 1975, s.1.22-1.26).

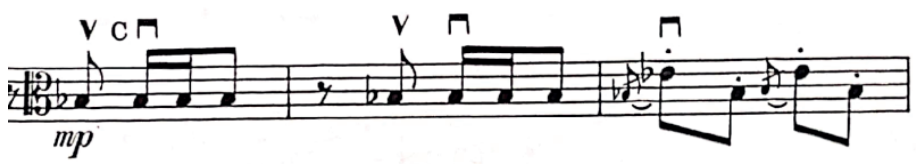

Figure 17. Shostakovich, Sonata for Viola and Piano Op. 147, 2nd movement bars 75-77 (Shostakovich, 1975, p.8)

In the next passage Druzhinin uses ricochet to emphasize the rhythmical character (Figure 18, Druzhinin, 1975, s.5.27-5.32).

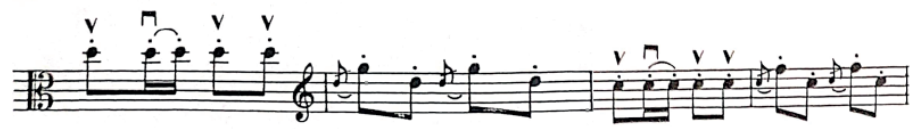

Figure 18. Shostakovich, Sonata for Viola and Piano Op. 147,

2nd movement bars 262-265 (Shostakovich, 1975, p.11-12)

\section{Third Movement - Adagio}

Finally, the third movement is informally subtitled "in the memory of the great composer" and presents the most substantial part of the sonata. Especially the compositional style in this movement is of particular interest, with it being fragmented largely due to the number of quotations ranging from Beethoven's Moonlight Sonata (Figure 19) to self-quotations from many of Shostakovich's own symphonies (Wilson, E., 2012: 83-94).

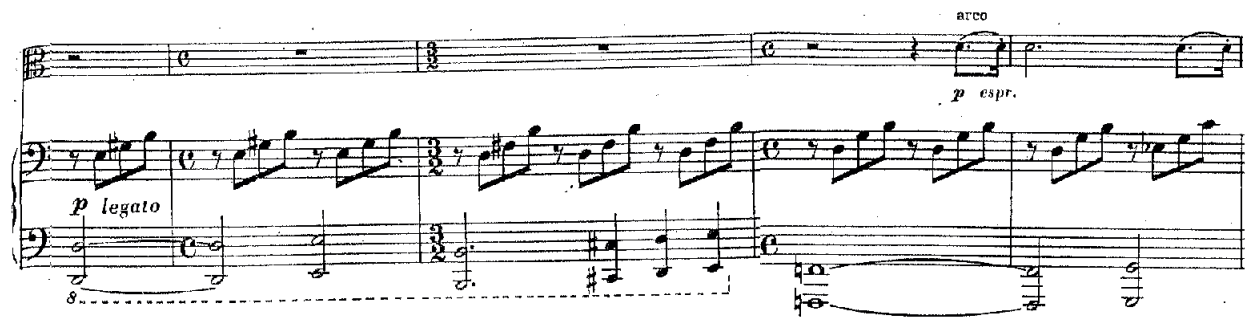

Figure 19. Shostakovich, Sonata for Viola and Piano Op. 147 (Score),

3rd movement bars 13-17 (Shostakovich, 1975, p.34) 
The following solo passage shows a great example of evolution through a wide range of dynamics from piano to forte leading to the section of explosions with dynamics marked fortissimo supported with double stops and triple stops written in viola. In Druzhinin's viola part all the bowings and fingerings are precise and can be taken as a reference when interpreting the section. It can be seen that he chose to play the bass-line passage starting from 104 on the C string to keep the power and the tension (Figure 20).
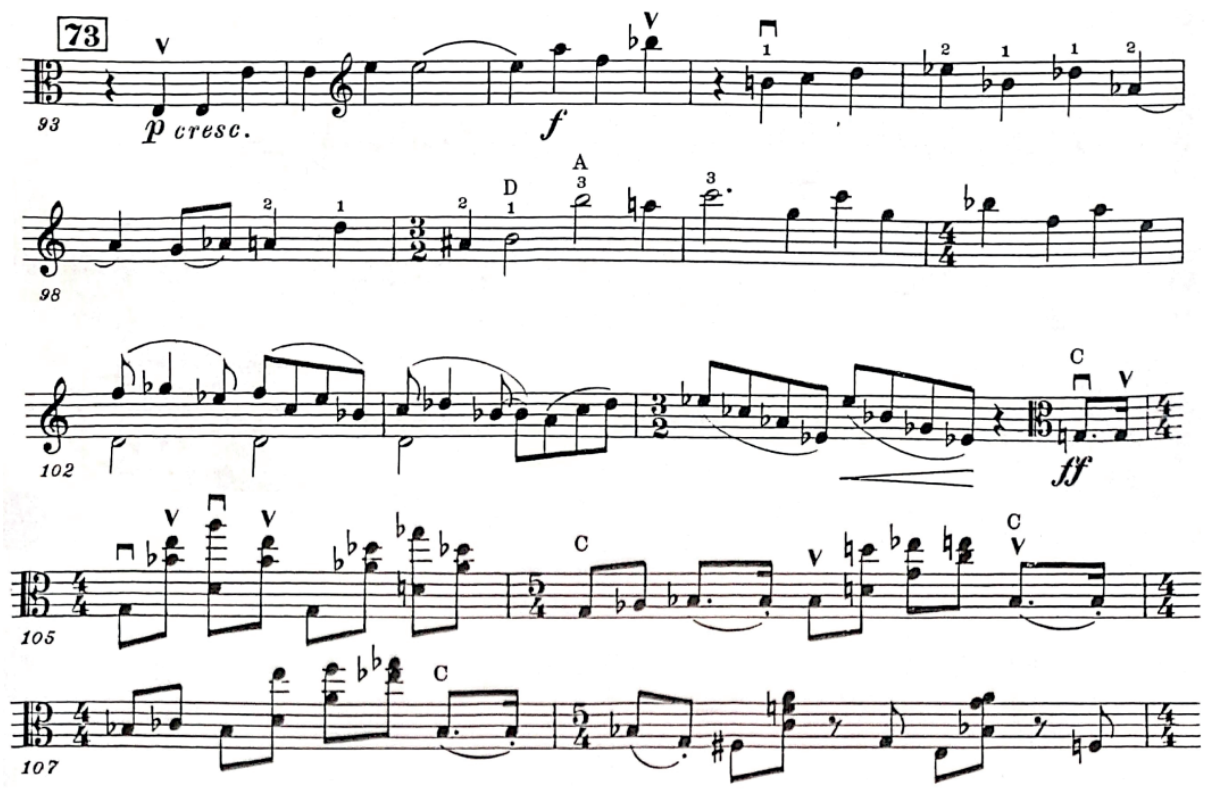

Figure 20. Shostakovich, Sonata for Viola and Piano Op. 147,

3rd movement bars 93-108 (Shostakovich, 1975, p.14)

The following passage which has three and four note chords is advised to be played with up and down bows to resonate the open strings more (Figure 21).

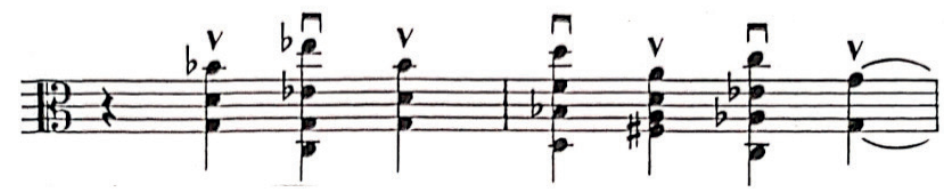

Figure 21. Shostakovich, Sonata for Viola and Piano Op. 147

3rd movement bars 110-111(Shostakovich, 1975, p.15) 
After the resolution section with Beethoven's Moonlight Sonata quotation, a chorale-like section starts. The viola part is marked espressivo and the sound is weakened by the use of a mute. Druzhinin supports this effect by playing double stops on the $\mathrm{C}$ and $\mathrm{G}$ strings using vibrato to achieve an intimate sound (Figure 22, Druzhinin, 1975, s.11.39-11.54).

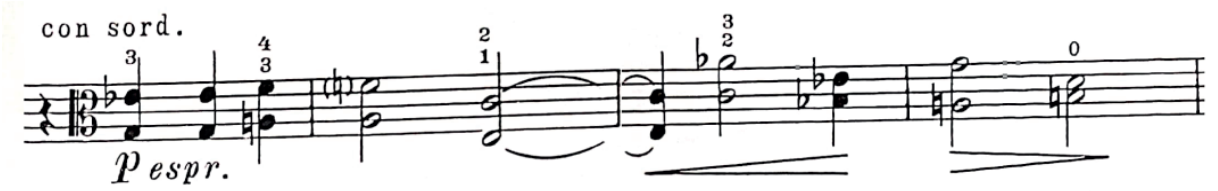

Figure 22. Shostakovich, Sonata for Viola and Piano Op. 147, 3rd movement bars 160-163 (Shostakovich, 1975, p.16)

At the end of the chorale-like section after the viola's long holding of the open $\mathrm{C}$ string, a quotation from Strauss' Don Quixote (Figure 23) marked in pianissimo in A flat major unexpectedly interrupts. Druzhinin avoids position change in this passage as well as interpreting with non vibrato and fluent bow (Figure 24).

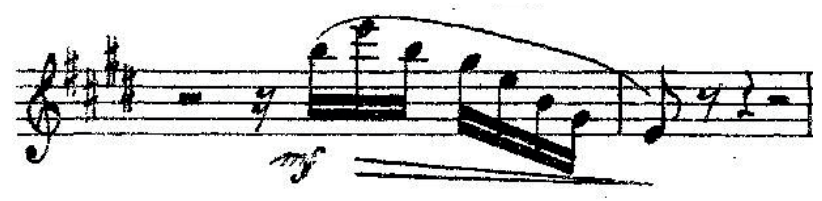

Figure 23. Strauss, Don Quixote Op. 35 eight bars after figure 82 clarinets (Strauss, 1999, p.8)

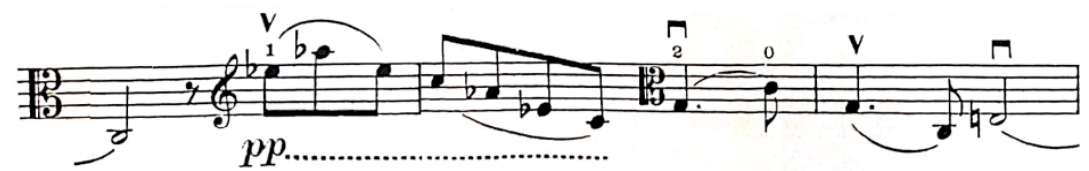

Figure 24. Shostakovich, Sonata for Viola and Piano Op. 147,

3rd movement bars 181-183 (Shostakovich, 1975, p.16) 


\section{Conclusion}

In this study an overview of Dmitri Shostakovich's life and information about the viola sonata is given to provide background knowledge to the performers before practicing his works. The conditions in which the composer lived and how the sonata is written are given to enhance the performer's knowledge. Additionally, information about the themes in this sonata is given to inspire performers to investigate related works. Lastly, extracts from F. Druzhinin's viola part are examined to give performers useful suggestions about fingerings and bowings when studying/interpreting the piece. Books, articles, sheet music and F. Druzhinin's recordings are used as resources.

The study made is valuable for performers who wish to interpret this sonata which combines historical knowledge and performance suggestions. Especially the section titled “performance suggestions given based on F. Druzhinin's viola part and recording" is particularly useful for the performers as practice and performance advice.

Hakem Değerlendirmesi: Dış bağımsız.

Çıkar Çatışması: Yazar çıkar çatışması bildirmemiştir.

Finansal Destek: Yazar bu çalışma için finansal destek almadığını beyan etmiştir.

Peer-review: Externally peer-reviewed.

Conflict of Interest: The author has no conflict of interest to declare.

Grant Support: The author declared that this study has received no financial support.

\section{References/Kaynakça}

Druzhinin, F., (Viola) \& Muntain, M. (Piano). (1975). Shostakovich: Sonata for Viola and Piano in C Major. Retrieved from https://www.youtube.com/watch?v=oEDzT1rI7vU (20.11.2020)

Druzhinin, F., (Viola) \& Muntain, M. (Piano). (1975). Shostakovich: Sonata for Viola and Piano in C Major. Retrieved from https://www.youtube.com/watch?v=pavHqdlBGTQ (20.11.2020)

Druzhinin, F., (Viola) \& Muntain, M. (Piano). (1975). Shostakovich: Sonata for Viola and Piano in C Major. Retrieved from https://www.youtube.com/watch?v=TzFZkT741ik\&t=24s (20.11.2020)

Fay, L.E.(2000). Shostakovich: A Life. New York: Oxford University Press.

MacDonald, M.(2008). Shostakovich's string concertos and sonatas. Fanning D. \& Fairclough P. (Eds.), Cambridge Companion to Shostakovich (139-143, 280-281) Cambridge University Press.

Maurice, D.(2000). Schostakovich's Swansong. Journal of the American Viola Society, Vol. 16 No. 1, 13-20

Roseberry, E.(1982). Shostakovich - his life and times. Kent: Midas Books.

Schostakowitsch, D. (1975). Sonate für Viola und Klavier [Sonata for Viola and Piano], [Musical Score]. Musikverlag Hans Sikorski, Hamburg. 
Shostakovich, D. (1981). The Gamblers Op. 63 - Opera (Scenes after N.V.Gogol), [Musical Score], G. Rozhdestvensky (Ed.), Moscow: State Publishers.

Shostakovich, D. (1984). Sonata for Viola and Piano Op. 147 [Viola part edited by F. Druzhinin], Collected works in forty-two volumes: Vol. 38, Moscow: State Publishers.

Solokov, I. (2012). Moving Towards an Understanding of Shostakovich's Viola Sonata. trans. Wilson, E.(2012), Ivashkin, A. \& Kirkman A. (Eds.), Contemplating Shostakovich: Life, Music and Film (80-94) Surrey: Ashgate.

Strauss, R. (1898). Don Quixote op. 35, [Musical Score], Jos. Aibl Verlag, Munich Retrieved from https://imslp. simssa.ca/files/imglnks/usimg/9/91/IMSLP52191-PMLP04977-StraussR-Op35.Clarinet.pdf

Volkov, S.(1979). Testimony: The Memoirs of Dmitri Shostakovich, trans. Antonina W. Bouisi, First Edition, London: Hamish Hamilton Ltd. UK. 